\title{
STRATEGI MARKETING MIX BAITUL MAL WA TAMWIL (BMT) UNIT GABUNGAN TERPADU (UGT) SIDOGIRI PASURUAN
}

\author{
Cihwanul Kirom \\ Sekolah Tinggi Agama Islam Negeri Kudus, Indonesia \\ E-mail: mukarrom1984@yahoo.com
}

\begin{abstract}
Within the business realm, marketing is a key factor which determines the success of distribution. Therefore, strategy and innovation are a necessity. Marketing activity would ensure whether a certain product is delivered to the costumers. In order to achieve the desired goals of marketing, it is important to manufacturers to follow a set of marketing processes, which comprise market overview, marketing strategy, marketing mix, and evaluation. Marketing mix is a set of strategies consist of product, price, promotion, and distribution, which guarantee the success of marketing activities. All of these aspects are intended to attain responses from the targeted market. The article seeks to discuss the marketing mix strategy implemented by BMT UGT Sidogiri Pasuruan based on four "Ps", namely product, price, place, and promotion. The study finds that the marketing mix strategy employed by BMT UGT has met the costumers' needs in terms of product strategy, pricing strategy, distribution strategy, and promotion strategy. The study also concludes that the proper implementation of marketing mix strategy and its compatibility with Islamic sharî́'ah as well as the organization's obedience towards Islamic business ethics are among pivotal factors that have significantly influenced the development of BMT UGT Sidogiri.
\end{abstract}

Keywords: Strategy; marketing mix; sharî' ${ }^{6} a h$.

\section{Pendahuluan}

Pada era globalisasi sekarang ini, persaingan bisnis semakin ketat dan menantang. Persaingan ini, tidak terkecuali, juga dihadapi oleh lembagalembaga keuangan sharî́ah. Untuk bisa eksis dan berkembang di tengahtengah persaingan tersebut dibutuhkan strategi-strategi dan terobosan- 
terobosan yang baik dan tepat sasaran. Dengan demikian, suatu lembaga keuangan sharî'ah tidak cukup hanya menggantungkan diri pada produk, layanan dan sumber daya manusia tetapi juga dituntut memiliki marketing strategy (strategi pemasaran) yang bagus.

Pemasaran sendiri merupakan suatu proses sosial dan manajerial (social-managerialprocess) di mana individu dan kelompok mendapatkan apa yang mereka butuhkan dan inginkan dengan menciptakan, menawarkan dan secara bebas mempertukarkan (exchange) produk yang bernilai dengan pihak lain. ${ }^{1}$ Dalam dunia bisnis, pemasaran adalah salah satu aspek penting yang ikut menentukan kesuksesan suatu lembaga perusahaan. Oleh karena itu, dibutuhkan terobosan-terobosan dan strategi pemasaran yang tepat agar perusahaan tersebut bisa meraih apa yang ia inginkan dari para konsumen/nasabah. Pemasaran jasa keuangan merupakan usaha untuk menciptakan dan melayani permintaan nasabah sehingga baik lembaga keuangan maupun masyarakat memperoleh apa yang mereka inginkan dari suatu transaksi keuangan.

Kegiatan pemasaran sangat menentukan sampai atau tidaknya produk yang dihasilkan oleh perusahaan kepada konsumen, sehingga kegiatan pemasaran sangat penting di mana para pelaku bisnis harus bisa menetapkan marketing mix (bauran pemasaran) yang tepat yang bisa digunakan untuk memenuhi keinginan konsumen. Untuk mendapatkan hasil pemasaran yang sesuai dengan harapan, maka produsen harus mengikuti tahapan atau proses pemasaran sebagai berikut: pengenalan pasar, strategi pemasaran, bauran pemasaran, dan evaluasi.

Dari beberapa proses pemasaran, bauran pemasaran merupakan tahapan ketiga dalam kegiatan pemasaran. Di dalam bauran pemasaran sendiri terdapat empat macam bauran yang dapat dijadikan sebagai salah satu pedoman dalam melaksanakan pemasaran. Keempat macam bauran tersebut lazim disebut dengan istilah 4P yang merupakan kependekan dari product, price, place dan promotion. Masing-masing bauran tersebut mempunyai tujuan tersendiri dalam kegiatan pemasaran. Untuk mencapai tujuan perusahaan, di mana yang terpenting antara lain adalah mencapai laba yang optimal serta untuk bertahan, perusahaan menggunakan kegiatan pemasarannya sebagai ujung tombak keberhasilan mencapai tujuan tersebut. Oleh karena itu, sebuah perusahaan harus dapat mengorganisir tiap-tiap bauran pemasaran tersebut agar teratur dengan

\footnotetext{
${ }^{1}$ Philip Kotler, Manajemen Pemasaran (Jakarta: Prenhallindo, 2002), 7.
} 
baik, sehingga pada gilirannya perusahaan mencapai tujuan dan hasil yang optimal.

Bauran pemasaran sendiri merupakan langkah lanjutan yang sudah memasuki wilayah pasar. Bauran pemasaran adalah serangkaian variable pemasaran terkendali yang dipakai oleh perusahaan untuk menghasilkan tanggapan yang dikehendaki perusahaan dari pasar sasarannya (konsumen). ${ }^{2}$ Sementara itu, produk merupakan kombinasi barang dan jasa yang ditawarkan pengusaha kepada pelanggan. Dalam hal ini produk adalah apa saja yang dapat ditawarkan oleh perusahaan di pasar untuk mendapatkan perhatian, permintaan, pemakaian atau konsumsi yang dapat memenuhi keinginan dan kebutuhan konsumen. ${ }^{3}$ Meskipun demikian, dalam perspektif Islam barang dan jasa yang ditawarkan tersebut haruslah merupakan produk halal. Dengan demikian, transaksi atas barang dan jasa (produk) yang haram menjadi batal demi hukum sharî́ah. ${ }^{4}$

Harga, sebagai komponen selanjutnya dari bauran pemasaran, merupakan pencerminan dari nilai suatu produk. Dalam teori ekonomi, harga, nilai dan faedah merupakan istilah-istilah yang saling berhubungan. Faedah adalah atribut barang yang dapat memuaskan kebutuhan, sementara nilai adalah ungkapan secara kuantitatif tentang kemampuan barang agar dapat menarik dalam pertukaran. Karena perekonomian kita saat ini sudah tidak lagi menggunakan sistem barter, maka untuk mengadakan pertukaran dan/atau untuk mengukur nilai suatu barang kita menggunakan alat tukar yang disebut uang. Dalam konteks ini, karena istilah yang dipakai adalah harga, maka harga adalah nilai yang dinyatakan dalam mata uang rupiah. ${ }^{5}$

Komponen terakhir dari bauran pemasaran adalah promosi. Promosi merupakan aspek penting dalam suatu kegiatan pemasaran sebagai salah satu cara efektif memberikan informasi kepada calon konsumen atau masyarakat luas. Promosi, dalam hal ini, juga merupakan salah satu ujung tombak dalam pemasaran. Dengan adanya promosi, perusahaan dapat memperoleh kesempatan untuk berkomunikasi secara langsung dengan konsumen.

\footnotetext{
2 Philip Kotler, Marketing Essentials, terj. Herujati Purwoto (Jakarta: Erlangga, 1999), 4.

${ }^{3}$ Murti Sumarni, Marketing Perbankan (Yogyakarta: Liberty, 1997), 22.

${ }^{4}$ M. Syafi'i Antonio, Bank Syariah dari Teori ke Praktek, (Jakarta: Gema Insani, 2001), 30.

5 Irawan dan Farid Wijaya M., Pemasaran: Prinsip dan Kasus, Edisi Kedua (Yogyakarta: BPFE, 1997), 110.
} 
Promosi dalam level praktisnya menunjuk pada berbagai kegiatan yang dilakukan perusahaan untuk mengkomunikasikan kebaikan produknya, membujuk dan mengingatkan para pelanggan dan konsumen sasaran untuk membeli produk tersebut. Karena itulah lazim kita lihat bagaimana perusahaan gencar melakukan pemasangan iklan, menyelenggarakan promosi penjualan, mengatur publikasi dan menyebarkan tenaga penjualan untuk mempromosikan produk-produknya. ${ }^{6}$

Setelah promosi dilakukan maka ada hal lain yaitu distribusi yang juga merupakan hal penting bagi suatu perusahaan mencapai tujuan yang diinginkan. Hal ini karena distribusi merupakan satu-satunya kegiatan pemasaran yang menjamin bahwa suatu produk sampai ke pasar. Distribusi juga sering disebut dengan saluran distribusi. Menurut Kotler, saluran distribusi adalah himpunan perusahaan dan perorangan yang mengambil alih hak atau membantu dalam pengalihan hak atas barang atau jasa selama berpindah dari produsen ke konsumen. ${ }^{7}$

Dari pemaparan di atas bisa disimpulkan bahwa kegiatan bauran pemasaran-dengan berbagai komponennya-sangat menentukan sampai atau tidaknya produk yang dihasilkan perusahaan kepada konsumen. Dengan demikian, bauran pemasaran merupakan salah satu aspek penting bagi para pelaku bisnis baik untuk mencapai tujuan bisnis mereka maupun untuk memenuhi keinginan konsumen.

\section{Konsep Umum dan Perspektif Islam tentang Pemasaran}

Pemasaran bermula dari kenyataan bahwa manusia adalah mahluk yang memiliki keinginan dan kebutuhan. Kebutuhan dan keinginan itu menciptakan suatu keadaan yang tidak menyenangkan dalam diri seseorang yang harus dipecahkan melalui pemilikan produk untuk memuaskan kebutuhan dan keinginan tersebut. Karena beberapa produk dapat memuaskan kebutuhan tertentu, maka pemilihan atas produk dituntun oleh konsep nilai dan kepuasan yang diharapkan.

Pemasaran sendiri merupakan proses sosial (social process) di mana individu dan kelompok mendapat apa yang mereka butuhkan dan inginkan dengan menciptakan dan mempertukarkan produk dan nilai dengan individu atau kelompok lainya. Definisi ini bertumpu pada konsep pokok tentang kebutuhan, keinginan, permintaan, produk, nilai,

\footnotetext{
${ }^{6}$ Irawan dan Farid, Pemasaran: Prinsip dan Kasus, 153.

7 Ibid., 134.
} 
pertukaran, transaksi pasar, pemasaran dan pemasar. ${ }^{8}$ Dengan kata lain, penciptaan dan pertukaran produk dan nilai di antara individu maupun kelompok menciptakan proses sosial yang menjadi basis bagi terjadinya kegiatan pemasaran.

Konsep pemasaran (marketing concept) berpendapat bahwa kunci untuk mewujudkan tujuan organisasi terletak pada kemampuan organisasi dalam menciptakan, memberikan dan mengkomunikasikan nilai pelanggan' (customer value; rasio antara apa yang diperoleh pelanggan dan apa yang ia diberikan/keluarkan) kepada pasar sasarannya secara lebih efektif dibandingkan para pesaing. Konsep ini bertumpu pada empat pilar utama, yaitu: pasar sasaran, kebutuhan pelanggan, pemasaran terintegrasi (integrated marketing) dan profibilitas. ${ }^{10}$

Konsep pemasaran didasarkan pada pandangan dari luar ke dalam. Konsep ini diawali dengan mendefinisikan pasar yang jelas yang berfokus pada kebutuhan pelanggan, memadukan semua sistem kegiatan yang akan mempengaruhi pelanggan dan menghasilkan laba melalui pemuasan pelanggan. Konsep pemasaran, sebagaimana disebut di atas, bersandar pada empat pilar utama dengan penjabarannya sebagai berikut: pertama, pasar sasaran. Tidak ada perusahaan yang dapat beroperasi di semua pasar dan memuaskan semua kebutuhan dan juga tidak ada perusahaan yang dapat beroperasi dengan baik dalam pasar yang luas, sehingga jika suatu perusahaan ingin berhasil maka ia harus dapat mendefinisikan pasar sasaran mereka dengan cermat dan menyiapkan program pemasaran. Kedua, kebutuhan pelanggan. Memahami kebutuhan dan keinginan pelanggan tidak selalu merupakan tugas yang sederhana. Hal ini dikarenakan beberapa pelanggan memiliki kebutuhan sendiri yang tidak mereka sadari atau mereka tidak dapat mengutarakan kebutuhankebutuhannya. Dengan demikian, suatu perusahaan dituntut untuk mampu memahami dengan baik kebutuhan konsumen. Semakin baik suatu perusahaan memahami kebutuhan konsumen dan mampu memenuhinya, akan semakin mudah ia mencapai target yang diinginkan.

Ketiga, pemasaran terpadu. Jika semua departemen bekerjasama melayani kepentingan pelanggan maka hasilnya adalah pemasaran

8 Ibid., 153.

${ }^{9}$ Nilai pelanggan bisa dirumuskan sebagai berikut: Nilai pelanggan $=($ Manfaat - Biaya $)$ $=($ Manfaat Fungsional + Manfaat Emosional) $/$ (Biaya Moneter + Biaya Waktu + Biaya Energi + Biaya Psikis).

${ }^{10}$ Gregorius Candra, Strategi dan Program Pemasaran (Yogyakarta: Andi Offset, 2005), 2. 
terpadu. Pemasaran terpadu berjalan dalam dua tahap yaitu: (a). Beragam fungsi pemasaran, tenaga penjualan periklanan, manajemen produk, riset pemasaran dan lainnya harus bekerjasama; (b). Pemasaran harus dikoordinasikan dengan baik pada bagian lain perusahaan. Keempat, profitabilitas. Tujuan utama konsep pemasaran adalah membantu organisasi mencapai tujuan mereka.

Sementara itu dalam pandangan Islam pemasaran merupakan suatu penerapan disiplin strategis (strategic discipline) yang sesuai dengan nilai dan prinsip sharî́ah. Hal inilah yang kemudian memunculkan ide mengenai pemasaran shari'ah (sharíah marketing). Ide ini sendiri ditelurkan oleh dua orang pakar di bidang pemasaran sharî'ah, yaitu Hermawan Kertajaya_salah satu dari lima puluh orang guru yang telah mengubah masa depan dunia pemasaran bersama-sama dengan Philip Kotler-dan Muhammad Syakir Sula salah satu dari enam orang pemegang gelar profesional ahli asuransi sharî‘'ah.

Sharíah marketing adalah sebuah disiplin bisnis strategis yang mengarahkan proses penciptaan, penawaran, dan perubahan value dari satu inisiator kepada stakeholder-nya, yang dalam keseluruhan prosesnya sesuai dengan akad dan prinsip-prinsip mu âmalah (bisnis) dalam Islam. ${ }^{11}$ Marketing menganjurkan agar setiap orang dalam bisnis selayaknya memiliki perilaku sebagai marketer sehingga mampu menggerakkan perusahaan, melihat, merespons, dan membuat pelanggan puas (customer satisfaction) dalam pasar yang terus menerus berubah-ubah. Oleh karena itulah ada beberapa aktivitas bisnis yang jelas secara tegas dilarang oleh Islam, yaitu: ${ }^{12}$

1. Melakukan transaksi bisnis yang diharamkan oleh Islam;

2. Mencari dan menggunakan harta dengan cara yang tidak halal;

3. Bersaing dengan cara batil;

4. Memasarkan makanan dan minuman yang dilarang sharî‘ $a$;

5. Menjelek-jelekkan produk dan/atau orang lain;

6. Menjadi aktor pamer aurat untuk menarik pelanggan;

7. Menipu/berbohong untuk meningkatkan transaksi.

11 Hermawan Kertajaya dan Muhammad Syakir Sula, Syariab Marketing (Bandung: Mizan, 2006), 26-27.

12 Ali Hasan, Marketing Bank Syariah (Yogyakarta: Mitra Pustaka, 2007), 22. 
Ada empat karakteristik yang terdapat pada pemasaran sharî‘ $a{ }^{\prime},{ }^{13}$ yaitu: pertama, ketuhanan (rabbânîyah). Salah satu ciri khas pemasaran shari'‘ ah adalah sifatnya yang religius. Jiwa seorang shari'ah marketer meyakini bahwa hukum-hukum sharî‘ ah yang bersifat ketuhanan merupakan hukum yang paling adil, sehingga ia akan mematuhinya dalam setiap aktivitas pemasaran yang dilakukan. Dalam setiap langkah, aktivitas dan kegiatan yang dilakukan seorang sharíah marketer harus selalu menginduk kepada sharî‘ah Islam. Bagi seorang shari'ah marketer, meskipun ia tidak mampu melihat Allah, ia akan selalu merasa bahwa Allah senantiasa mengawasinya. Sehingga ia akan menghindarkan dirinya dari segala macam perbuatan yang menyebabkan orang lain tertipu atas produk-produk yang dijualnya. Hal ini karena seorang sharíah marketer akan selalu merasa bahwa setiap perbuatan yang ia lakukan akan diperhitungkan di akhirat nanti, sebagaimana ditegaskan ayat dalam alQur'ân surat al-Zalzalah ayat 7-8.

Kedua, etis (akblâqîyah). Keistimewaan lain dari sharî́ah marketer adalah mengedepankan masalah akhlak dalam seluruh aspek kegiatannya. Pemasaran sharî́ah adalah konsep pemasaran yang sangat mengedepankan nilai-nilai moral dan etika tanpa peduli dari agama apapun, karena hal ini bersifat universal. Ketiga, realistis (al-wâqi 'îyah). Pemasaran sharî‘'ah bukanlah konsep yang eksklusif, fanatis, antimodernitas, dan kaku, melainkan sebuah konsep pemasaran yang fleksibel. Shari'ah marketer bukanlah berarti bahwa para pemasar harus berpenampilan ala bangsa Arab dan mengharamkan dasi, namun sharí $a h$ marketer haruslah tetap berpenampilan bersih, rapi, dan bersahaja apapun model atau gaya berpakaian yang ia kenakan.

Keempat, humanis (insânîyah). Keistimewaan lain Sharîab marketing adalah sifatnya yang humanistis dan universal. Pengertian humanistis adalah bahwa sharî́ah diciptakan untuk manusia agar derajatnya terangkat, sifat kemanusiaannya terjaga dan terpelihara, serta sifat-sifat kehewanannya dapat terkekang dengan panduan sharî‘ ah. Sharî́ah Islam sendiri adalah sharíah bumanistis yang diciptakan untuk manusia sesuai dengan kapasitasnya tanpa memperdulikan ras, warna kulit, kebangsaan, dan status. Sehingga dengan demikian pemasaran sharî‘ah bersifat universal.

${ }^{13}$ Lebih terperind lihat dalam Kertajaya dan Sula, Syariah Marketing, 28-38. 
Dalam dunia pemasaran, seorang pemasar memegang dan memainkan peranan penting dalam menentukan tercapai atau tidaknya target pemasaran sebuah perusahaan. Dalam sudut pandang sharíah marketing ada sembilan etika pemasaran yang menjadi prinsip-prinsip sharî‘ ah marketer dalam menjalankan fungsi pemasaran, yaitu: ${ }^{14}$ memiliki kepribadian spiritual (taqwâ); berperilaku baik dan simpatik (sidq); berlaku adil dalam bisnis ('adl); bersikap melayani dan rendah hati (khidmah); menepati janji dan tidak curang; jujur dan terpercaya (amânab); tidak suka berburuk sangka; tidak suka menjelek-jelekkan; dan tidak melakukan sogok.

\section{Sejarah Singkat BMT UGT Sidogiri Pasuruan}

Berasal dari ide dan gagasan para guru tugas di Pondok Pesantren Sidogiri Pasuruan (berdiri tahun 17 September 1745) ${ }^{15}$ disebabkan keprihatinan mereka terhadap maraknya praktik rentenir di sekitar pesantren, maka mereka berinisiatif untuk mendirikan sebuah koperasi sharî‘ah bebas riba agar-selain bisa mengurangi praktik rentenir-juga membantu para guru yang mengabdi di pesantren tersebut. Salah satu tokoh yang berperan penting hingga saat ini adalah $\mathrm{H}$. Mahmud Ali Zain.

Pada tanggal 6 Juni 2000 atau 5 Rabî‘ al-Awwal 1421 H didirikanlah koperasi Baitul Mal wa Tamwil Usaha Gabungan Terpadu Sidogiri yang disingkat "BMT UGT Sidogiri" di Surabaya, yang kemudian mendapatkan Badan Hukum Koperasi dari Kanwil Dinas Koperasi PK dan M Propinsi Jawa Timur dengan SK Nomor: 09/BH/KWK.13/VII /2000 tertanggal 22 Juli 2000. BMT yang dimulai dengan modal awal 13,5 juta rupiah ini murni diprakarsai oleh para guru tugas di Pondok Pesantren Sidogiri Pasuruan. ${ }^{16}$ Dengan slogan "Memelihara Amanah Meraih Barokah", BMT UGT Sidogiri memulai percaturan di dunia lembaga keuangan sharî‘ah dan bertahan sampai saat ini. Bahkan, lembaga ini bisa dibilang sangat sukses karena telah memiliki cabang yang tersebar ke seluruh nusantara.

Keberhasilan BMT UGT Sidogiri memang terlihat sangat nyata. Hal ini dibuktikan, misalnya, dengan perkembangannya yang sangat signifikan dengan membuka beberapa unit pelayanan anggota di kabupaten/kota

\footnotetext{
14 Ibid., 67.

15 Redaksi Majalah Ijtihad, Jejak Langkah 9 Masyayikh Sidogiri, Jilid 2 (Pasuruan: Pustaka Sidogiri Pondok Pesantren Sidogiri, 1432 H), 29-30.

${ }^{16}$ Sholeh Wafi (Direktur Bisnis BMT UGT Sidogiri), Wawancara, Rabu 28 Januari 2015.
} 
yang dinilai potensial pada tiap tahun. BMT UGT Sidogiri sendiri saat ini berkantor pusat di Jl. Sidogiri Barat RT 03 RW 02 Sidogiri Kraton Sidogiri Kota Pasuruan Jawa Timur. Indikasi lain dari perkembangan BMT tersebut adalah bahwa pada tahun 2013 ia memiliki anggota sebanyak 8.871 orang. Pada tahun 2014 jumlah kenggotaan BMT UGT Sidogiri meningkat signifikan dengan jumlah 11.602 anggota yang tersebar di seluruh wilayah Jawa Timur, Jawa Barat, Bali, DKI Jakarta, Kalimantan, Lampung, Riau dan Bangka Belitung.

Setiap tahun, seperti disebut di atas, BMT UGT Sidogiri membuka beberapa unit pelayanan anggota di kabupaten/kota yang dinilai memiliki potensi untuk mengembangkan usahanya. Pengurus Pusat BMT UGT Sidogiri terus berusaha melakukan perbaikan dan pengembangan secara berkesinambungan pada semua bidang baik organisasi maupun usaha. Untuk menunjang hal tersebut, maka dibuatlah sebuah "rambu penuntun" bagi seluruh anggota koperasi dan penerima amanat yang disebut "Karakter STAF". STAF sendiri merupakan singkatan dari siddîq (jujur), tabligh (transparan), amânah (dapat dipercaya), dan fatânah (profesional). Kesemuanya merupakan nilai-nilai karakter utama yang harus dimiliki dan dipegang teguh baik oleh pengelola maupun anggota lembaga keuangan tersebut. Selain itu BMT UGT Sidogiri juga memperkuat jaringan kemitraan, baik dengan lembaga perbankan maupun non-perbankan. Dalam hal ini, BMT UGT Sidogiri memperoleh dana kemitraan sebesar 200 miliar rupiah dari Bak Syariah Mandiri (BSM) dan BRI Syariah sebagai komitmen pengembangan sektor riil sharî́ah. ${ }^{17}$ Pesatnya perkembangan BMT UGT Sidogiri juga dibuktikan dengan bertambahnya jumlah nasabah, karyawan dan unit layanan. Hingga Pada bulan Desember tahun 2014, misalnya, jumlah keseluruhan unit pelayanan simpan pinjam BMT UGT Sidogiri adalah 257 kantor.

\section{Strategi Bauran Pemasaran BMT UGT Sidogiri Pasuruan}

\section{Strategi produk}

Produk yang ditawarkan oleh BMT UGT Sidogiri sesuai dan memegang prinsip-prinsip sharî‘'ah, dengan didasari unsur-unsur kejujuran, serta tidak mengandung unsur terlarang dalam Islam di dalamnya seperti tadlîs, maysir, asusila, najs, gharar, barang haram, żulum,

17 http://www.republika.co.id/berita/ekonomi/syari'ah-ekonomi/15/02/23 /nk89rmbmt-sidogiri-raih-dana-kemitraan-rp-200-miliar. (20 April 2015). 
iḅtikâr, ribâ dan rishwah. Produk yang ditawarkan oleh BMT UGT Sidogiri juga sangat beraneka ragam dan variatif, mulai dari produk simpanan [produk simpanan yang bersifat tabungan biasa (tabungan umum sharî‘ ah) atau tabungan untuk kebutuhan khusus seperti tabungan haji, tabungan umrah, tabungan idul fitri, tabungan qurban, tabungan pendidikan (tabungan lembaga peduli siswa, tabungan tarbiyah) serta tabungan investasi keuangan (tabungan mudârabah berjangka dan mudârabah berjangka Plus)], produk pembiayaan [mulai dari gadai emas sharî‘ah, modal usaha (UGT MUB), biaya pendidikan dan biaya rawat inap rumah sakit (UGT MTA), pembiayaan kendaraan bermotor (UGT $\mathrm{KBB}$ ), pembelian barang elektronik (UGT PBE), sampai dengan pembiayaan kafâlah haji (UGT PKH)], produk jasa dan produk perumahan, sehingga apa yang dibutuhkan oleh nasabah bisa tercover. Berbagai produk pada BMT UGT Sidogiri tersebut mempunyai dan mengedepankan motif kemaslahatan, kebutuhan dan kewajiban, dan berdasarkan pertimbangan kemaslahatan (altruistic consideration). Hal-hal tersebut sejalan dengan apa yang dikemukakan oleh, misalnya, Muhammad Abdul Manan dan M.M. Metwally yaitu bahwa asumsiasumsi produk bank harus dilakukan untuk jasa halal dengan proses produk bank dan pasca-produk bank yang tidak menimbulkan madarrah. ${ }^{18}$

Strategi produk (product strategy) pada BMT UGT Sidogiri menggunakan strategi positioning produk yaitu suatu strategi menciptakan diferensiasi yang unik dalam benak pelanggan sasaran, sehingga terbentuk citra atau merek yang lebih unggul dibandingkan dengan merek/produk pesaing. Dalam hal ini, produk yang ditawarkan oleh BMT UGT Sidogiri, baik produk-produk funding (penghimpunan dana) dan landing (penyaluran dana), justru tidak menggunakan istilah-istilah Arab secara keseluruhan tetapi dengan menggunakan istilah Indonesia dan Arab (campuran) agar mudah difahami oleh nasabah.

Strategi lain yang diterapkan pada produk BMT UGT Sidogiri adalah dengan memberi motto khusus pada per-item produk dengan frasa berisi motivasi yang baik. Hal ini seperti, misalnya, yang ada pada UGT MUB (Modal Usaha Barokah) dengan motto "pilihan cerdas meraih berkah", pada PKH (Pembiayaan Kafalah Haji) dengan motto "pilihan cara mudah menuju tanah suci", pada produk tabungan umum sharî‘ah dengan motto

18 Herry Susanto dan Khaerul Umam, Manajemen Pemasaran Bank Syariah (Bandung: Pustaka Setia, 2013), 344. 
"keuntungan melimpah, bebas riba dan penuh berkah", dan pada Tabungan MDA berjangka dengan motto "cara investasi mudah, menguntungkan dan menentramkan". Pemberian berbagai motto tersebut merupakan bagian dari strategi produk karena motto adalah serangkaian kata-kata yang mencerminkan visi dan misi suatu lembaga dalam melayani masyarakat. Dengan motto sebuah produk akan memiliki arti positif, menarik perhatian dan mudah diingat. ${ }^{19}$

Tidak hanya melabeli produk-produknya dengan motto, untuk menarik nasabah BMT UGT Sidogiri juga menggunakan acronym (singkatan). Selain untuk menarik konsumen, hal tersebut ditujukan untuk memudahkan nasabah dalam mengingat produk-produk yang ditawarkan yang memang sangat variatif. Hal ini bisa dilihat dalam produk pembiayaan seperti UGT GES, UGT MUB, UGT MTA, UGT KBB, UGT PBE dan UGT PKH.

Dapat disimpulkan bahwa beberapa strategi tersebut di atas bertujuan untuk: 1). Memberikan ciri khas pada produk agar tidak sama dengan produk-produk sejenis yang ditawarkan oleh kompetitor; 2). Membina citra, yaitu dengan memberikan keyakinan, jaminan kualitas serta prestige tertentu kepada konsumen/nasabah; dan 3). Memberikan ciri khas (uniqueness) pada produk lembaga keuangan sharî‘ah yang ditawarkan.

Dalam kaitanya dengan strategi positioning produk, BMT UGT Sidogiri menyosialisasikan produknya dengan menggunakan beberapa kata dan frasa yang menjelaskan sekaligus menegaskan bahwa produk yang ditawarkan kepada konsumen sesuai dengan sharî́ah dan terbebas dari unsur riba. Kata dan frasa yang digunakan adalah "aman", "menguntungkan", "kompetitif" dan "bebas dari riba". Kata "aman" mengandung makna bahwa produk BMT UGT Sidogiri sesuai dengan sharî‘'ah. Kata "menguntungkan" merupakan penjelasan tentang sistem bagi hasil (mudârabah) yang diberikan pada setiap produk pembiayaan maupun penghimpunan BMT. Kata "kompetitif' berarti bahwa nasabah mendapat porsi yang tepat sesuai dengan item produk dan jangka waktu yang dipilih. Adapun frasa "bebas dari riba" mengandung penekanan bahwa akad yang digunakan dalam setiap transaksi adalah sesuai dengan sharî‘ ah dan bisnis berlandaskan ajaran Islam.

${ }^{19}$ Kasmir, Pemasaran Bank, Edisi Revisi (Jakarta: Prenada Media, 2008), 127. 
Meskipun BMT UGT Sidogiri menyematkan motto dan istilah-istilah sebagaimana di atas pada setiap produknya, namun ia tidak memiliki produk andalan sebagaimana lembaga keuangan lainnya. Artinya, pada BMT UGT Sidogiri, semua produk adalah sama, baik produk pembiayaan, produk simpanan, produk jasa maupun produk perumahan. Setiap produk menempati posisi strategis yang sama sesuai dengan porsinya masing-masing. Dengan demikian tidak ada semacam "skala prioritas" yang diperuntukkan bagi produk tertentu.

Sebagai ilustrasi, produk perumahan yang dimiliki oleh BMT UGT Sidogiri saat ini adalah Green Giri Village (tipe 36/72) dan Pasuruan Regency (tipe 40 dan 45). Akad yang digunakan dalam produk perumahan ini adalah akad jual beli istithnâa (apabila rumah belum dibangun/masih berbentuk tanah kavling). Sedangkan untuk rumah sudah jadi, akad yang dipakai adalah jual beli murâbaḥah. Dalam hal besaran nisbah maka itu merupakan hasil kesepakatan antara BMT UGT Sidogiri dan nasabah.

Ilustrasi berikutnya adalah tentang produk jasa yang dimiliki oleh BMT UGT Sidogiri di mana salah satu diantaranya adalah "layanan transfer" yang mulai dioperasikan pada tanggal 1 Oktober 2012. Produk jasa ini bertujuan untuk memudahkan nasabah bertransaksi online antarbank dan/atau antarjaringan BMT UGT Sidogiri. BMT UGT Sidogiri juga menyediakan Payment Point Online Banking yang merupakan loket pembayaran online via bank. Untuk produk ini BMT UGT Sidogiri bekerja sama dengan Bank Danamon Syariah dan PT. VSI (Value Stream Internasional). Produk jasa ini, antara lain, melayani pembayaran listrik, dan telpon.

Sebagai lembaga keuangan yang dari awal melandaskan dirinya di atas nilai-nilai shari`‘ah, BMT UGT Sidogiri menekankan kepada seluruh karyawannya agar memiliki budaya kerja yang berbeda dari lembaga keuangan konvensional, sehingga mampu menjadi suatu keunggulan yang dapat sebagai nilai tambah daalm pandang nasabah. Budaya kerja yang ditekankan dan dikembangkan adalah budaya kerja yang telah diteladankan oleh Rasulullah SAW, yaitu siddîq, amânah, tablìgh, dan fatânah.

Nilai-nilai kerja tersebut pada gilirannya berpengaruh pada strategi produk yang ditawarkan oleh BMT UGT Sidogiri di mana setiap produk yang ditawarkan dijamin sepenuhnya bersesuaian dengan prinsip-prinsip sharî‘ah, mengedepankan nilai keadilan, keterbukaan dengan margin yang 
telah disepakati oleh nasabah, kesepakatan yang kompetitif dan tidak membebani nasabah.

Efektivitas strategi produk BMT UGT Sidogiri berdampak signifikan pada peningkatan jumlah nasabah, baik penabung maupun peminjam. Pada tahun 2013, misalnya, jumlah penabung sebanyak 415.771 orang. Tahun 2014 jumlah tersebut meningkat menjadi 544.169 orang. Adapun jumlah peminjam pada tahun 2013 sebanyak 98.128 orang dan pada tahun 2014 meningkat menjadi 119.660 penabung. Tabel berikut menjelaskan pertumbuhan simpanan BMT UGT Sidogiri dari 2001 s.d. 2014.

Tabel Pertumbuhan Simpanan BMT UGT Sidogiri

\begin{tabular}{|c|c|c|c|c|c|c|c|}
\hline No & $\begin{array}{c}\text { Tahu } \\
\text { n }\end{array}$ & Modal & $\begin{array}{c}\text { Tumbu } \\
\text { h } \\
(\%)\end{array}$ & Simpanan & $\begin{array}{c}\text { Tum } \\
\text { buh( } \\
\%)\end{array}$ & $\begin{array}{c}\text { Asset } \\
\text { (Kekayaan) }\end{array}$ & $\begin{array}{c}\text { Tumb } \\
\text { uh } \\
(\%)\end{array}$ \\
\hline 1 & 2001 & $\begin{array}{l}141.090 .0 \\
00\end{array}$ & - & 452.908 .000 & - & 826.895 .400 & - \\
\hline 2 & 2002 & $\begin{array}{l}495.635 .0 \\
00\end{array}$ & $251 \%$ & 682.549 .775 & $51 \%$ & 1.482 .530 .948 & $79 \%$ \\
\hline 3 & 2003 & $\begin{array}{l}595.896 .3 \\
00\end{array}$ & $20 \%$ & $\begin{array}{l}1.135 .457 .7 \\
75\end{array}$ & $66 \%$ & 2.927 .723 .305 & $97 \%$ \\
\hline 4 & 2004 & $\begin{array}{l}654.343 .0 \\
00\end{array}$ & $10 \%$ & $\begin{array}{l}4.096 .190 .0 \\
38\end{array}$ & $261 \%$ & 5.231 .130 .382 & $79 \%$ \\
\hline 5 & 2005 & $\begin{array}{l}1.480 .120 \\
.000\end{array}$ & $126 \%$ & $\begin{array}{l}8.326 .647 .0 \\
75\end{array}$ & $103 \%$ & 13.990 .537 .966 & $167 \%$ \\
\hline 6 & 2006 & $\begin{array}{l}3.715 .480 \\
.000\end{array}$ & $151 \%$ & $\begin{array}{l}17.954 .830 . \\
744\end{array}$ & $116 \%$ & 30.440 .110 .019 & $118 \%$ \\
\hline 7 & 2007 & $\begin{array}{l}6.724 .750 \\
.000\end{array}$ & $81 \%$ & $\begin{array}{l}31.176 .547 . \\
352\end{array}$ & $74 \%$ & 51.672 .554 .641 & $70 \%$ \\
\hline 8 & 2008 & $\begin{array}{l}12.035 .48 \\
0.000\end{array}$ & $79 \%$ & $\begin{array}{l}62.602 .493 . \\
556\end{array}$ & $101 \%$ & 89.380 .278 .098 & $73 \%$ \\
\hline 9 & 2009 & $\begin{array}{l}19.423 .83 \\
0.000\end{array}$ & $61 \%$ & $\begin{array}{l}92.249 .688 . \\
674\end{array}$ & $47 \%$ & $\begin{array}{l}133.242 .408 .13 \\
6\end{array}$ & $49 \%$ \\
\hline 10 & 2010 & $\begin{array}{l}33.575 .68 \\
0.000\end{array}$ & $73 \%$ & $\begin{array}{l}150.947 .479 \\
.950\end{array}$ & $64 \%$ & $\begin{array}{l}226.319 .513 .64 \\
7\end{array}$ & $70 \%$ \\
\hline 11 & 2011 & & $41 \%$ & & $76 \%$ & & $79 \%$ \\
\hline
\end{tabular}




\begin{tabular}{|c|c|c|c|c|c|c|c|}
\hline & & $\begin{array}{l}47.374 .04 \\
0.000\end{array}$ & & $\begin{array}{l}265.221 .225 \\
.244\end{array}$ & & $\begin{array}{l}406.198 .718 .75 \\
4\end{array}$ & \\
\hline 12 & 2012 & $\begin{array}{l}85.763 .26 \\
0.000 \\
\end{array}$ & $81 \%$ & $\begin{array}{l}450.193 .495 \\
.567 \\
\end{array}$ & $70 \%$ & $\begin{array}{l}662.771 .142 .56 \\
3\end{array}$ & $63 \%$ \\
\hline 13 & 2013 & $\begin{array}{l}164.434 .5 \\
50.000 \\
\end{array}$ & $92 \%$ & $\begin{array}{l}664.465 .294 \\
.636 \\
\end{array}$ & $48 \%$ & $\begin{array}{l}1.069 .163 .194 .2 \\
51\end{array}$ & $61 \%$ \\
\hline 14 & 2014 & $\begin{array}{l}245.136 .2 \\
80.000\end{array}$ & $49 \%$ & $\begin{array}{l}927.199 .657 \\
.567\end{array}$ & $40 \%$ & $\begin{array}{l}1.509 .559 .920 .7 \\
50\end{array}$ & $41 \%$ \\
\hline
\end{tabular}

Sumber: Laporan Buku Rapat Anggota Tahunan BMT UGT Sidogiri Tahun 2014

Marketing mix produk BMT UGT Sidogiri tidak melanggar etika sharî‘ ah. Hal ini terlihat, antara lain, dengan dimasukkannya unsur-unsur moral dan elemen rohaniah dalam proses pembuatan keputusan produksi untuk pengembangan produk. Selain itu dalam penentuan produkproduknya, lembaga ini menjunjung tinggi aspek kehalalan yang menjamin tidak akan munculnya kerusakan dalam bentuk apapun. Produk-produknya riil bukan maya dan bisa dikirim setelah penjualan terjadi. ${ }^{20}$

Strategi produk lain yang diterapkan oleh BMT UGT Sidogiri adalah menganggap konsumen sebagai mitra sejajar, di mana baik perusahaan sebagai penjual produk maupun konsumen sebagai pembeli produk berada pada posisi yang sama. Lembaga ini tidak menganggap para nasabahnya sebagai "sapi perah" untuk membeli produknya, tapi menjadikan konsumen sebagai mitra dalam pengembangan perusahaan. Hal ini berbeda dari pemasaran konvensional yang memposisikan konsumen sebagai objek untuk mencapai target penjualan semata. Dalam kasus seperti ini konsumen seringkali dirugikan karena mereka mendapatkan janji yang berbeda dari realitas. Setelah mendapatkan target penjualan, perusahaan tidak akan mempedulikan lagi konsumen yang telah membeli produknya dan tidak memikirkan kekecewaan konsumen. Hal negatif seperti ini sangat dijauhi oleh BMT UGT Sidogiri.

2. Strategi harga

Dalam hal penentuan harga dari sebuah produknya, BMT UGT Sidogiri mengutamakan nilai keadilan yang, memang, merupakan ciri dari bank sharî‘ah serta sesuai dengan etika sharî'ah dalam harga, yaitu persaingan secara sehat dan tanpa intervensi. ${ }^{21}$ Susanto dan Umam

20 Susanto dan Umam, Manajemen Pemasaran, 103.

21 Ibid., 102. 
menegaskan bahwa selain hal-hal tersebut, terdapat beberapa syarat penting dalam keberhasilan mekanisme pricing, yaitu mengharuskan tidak adanya corner market, tidak ada penimbunan, tidak ada manipulasi harga yang tidak adil dan tidak ada pembatasan pada perdagangan.

Pada akad bagi hasil dalam transaksi jual beli, BMT UGT Sidogiri memberi kesempatan bagi para nasabahnya untuk bernegoisasi terkait penentuan tingkat bagi hasil (margin/nisbah), sehingga penentuan hal tersebut berdasarkan kesepakatan kedua belah pihak tanpa adanya unsur mengutamakan/menguntungkan satu pihak. Selain itu kesepakatan awal atas suatu negoisasi merupakan kesepakatan yang berlaku hingga akhir transaksi, sehingga tidak akan memberatkan pihak nasabah. Hal ini berbeda dari lembaga keuangan konvensional di mana tingkat margin dapat berubah sesuai dengan perubahan tingkat suku bunga berdasarkan ketetapan Bank Indonesia.

Terkait penetapan harga, BMT UGT Sidogiri memberlakukan mekanisme yang relatif sama dengan beberapa BMT lain dan cukup kompetitif, di mana transaksi yang digunakan adalah sistem bagi hasil (bukan sistem bunga) dengan akad mudârabah/mushârakah sedangkan untuk akad jual beli digunakan sistem murâbaḥah. Dalam pelaksanaanya, bagi hasil (nisbah) sangat bervariasi tergantung pada produk yang dipilih oleh nasabah.

Sebagai ilustrasi, secara garis besar, akad yang dipakai dalam produk simpanan BMT UGT Sidogiri adalah mudârabah mushârakah yang merupakan perpaduan dari akad mudârabah dan mushârakah. BMT sebagai pihak yang menyertakan modal memperoleh bagian keuntungan berdasarkan porsi modal yang disertakan. Apabila terjadi kerugian maka BMT ikut menanggung kerugian tersebut sesuai porsi modal yang disertakan. Kisaran nisbah yang ditetapkan oleh BMT UGT Sidogiri adalah 40\% anggota dan 60\% BMT. Meskipun demikian, sebagaimana disebut di atas, pada beberapa item produk tingkatan nisbah bervariasi. Tabel di bawah ini memperlihatkan kisaran nisbah dalam tiap produk yang ditawarkan oleh BMT UGT Sidogiri.

Tabel Nisbah Produk-produk Keuangan BMT UGT Sidogiri

\begin{tabular}{|c|l|l|l|}
\hline No & Nama Produk & Anggota & BMT \\
\hline 1 & Tabungan Umum Syariah & $30 \%$ & $70 \%$ \\
\hline 2 & Tabungan Haji & $50 \%$ & $50 \%$ \\
\hline 3 & Tabungan Umroh & $40 \%$ & $60 \%$ \\
\hline
\end{tabular}




\begin{tabular}{|l|l|l|l|}
\hline 4 & Tabungan Idul Fitri & $40 \%$ & $60 \%$ \\
\hline 5 & Tabungan Lembaga Peduli Siswa & $40 \%$ & $60 \%$ \\
\hline 6 & Tabungan Qurban & $40 \%$ & $60 \%$ \\
\hline 7 & Tabungan Tarbiyah & $30 \%$ & $70 \%$ \\
\hline 8 & Tabungan Mudârabab Berjangka & - & - \\
\hline 9 & Tabungan Mudârabab Plus & $45 \%$ & $55 \%$ \\
\hline
\end{tabular}

Sumber: Brosur BMT UGT Sidogiri

Selain pembagian nisbah sebagaimana di atas, terdapat ketentuan pembagian nisbah tersendiri bagi Tabungan Mudârabah Berjangka di mana nisbah-nya disesuaikan dengan jangka waktu yang dipilih oleh nasabah dengan rincian sebagai berikut:

a) Jangka 1 bulan nisbah 50\% anggota dan 50\% BMT;

b) Jangka 3 bulan nisbah 52\% anggota dan 48\% BMT;

c) Jangka 6 bulan nisbah 55\% anggota dan 45\% BMT;

d) Jangka 9 bulan nisbah 57\% anggota dan 43\% BMT;

e) Jangka 12 bulan nisbah 60\% anggota dan 40\% BMT;

f) Jangka 24 bulan nisbah 70\% anggota dan 30\% BMT.

Strategi pricing lain yang diterapkan oleh BMT UGT Sidogiri adalah dengan memberikan semacam "prioritas" kepada nasabah yang benarbenar credible dan memiliki track record yang bagus. Dalam hal ini BMT memberikan plafon pembiyaan hingga maksimal 500 juta rupiah untuk nasabah-nasabah dimaksud. Syarat kredit pada BMT UGT Sidogiri juga cukup memudahkan nasabah sebagaimana BMT lainya, kecuali pada Kredit Modal Usaha di mana disyaratkan bahwa usaha yang dijalankan oleh nasabah harus sudah berjalan minimal satu tahun dan nasabah/anggota diharuskan membuat laporan penggunaan dana setiap satu bulan serta menyerahkan laporan perhitungan hasil usaha tiga bulan terakhir. Kemudahan syarat kredit pada BMT UGT Sidogiri terbukti mampu meningkatkan jumlah peminjam secara signifikan seperti telah diilustrasikan pada bagian strategi produk di atas.

Strategi harga yang juga diberlakukan oleh BMT UGT Sidogiri adalah jangka waktu kredit untuk tiap item produknya yang juga berbeda-beda dan variatif sesuai dengan pilihan nasabah/konsumen. Pada GES, misalnya, jangka maksimal kredit adalah empat bulan dan bisa diperpanjang maksimal dua kali; pada MUB jangka waktu kreditnya adalah 36 bulan; pada MTA jangka waktu pembiayaannya adalah satu tahun; pada KBB jangka waktu pembiayaannya maksimal lima tahun 
untuk kendaraan baru dan tiga tahun untuk kendaraan bekas; pada PBE jangka waktu kredit disesuaikan dengan jangka waktu garansi; dan pada PKH jangka waktunya adalah lima tahun.

3. Strategi lokasi dan distribusi

Dalam kaitanya dengan strategi lokasi/distribusi, BMT UGT Sidogiri memfokuskan diri pada tempat-tempat potensial, khususnya pasar-pasar tradisional. Selain menjadi tempat perputaran uang yang cepat dan sangat berpotensi untuk bisnis lembaga keuangan, lembaga ini juga memiliki tujuan utama yaitu untuk meminimalkan praktik rentenir yang sangat mungkin ada lokasi itu. Alasan lain adalah bahwa di pasar-pasar tradisional banyak pelaku ekonomi kecil yang membutuhkan bantuan modal untuk melakukan dan mengembangkan usaha.

Selain pasar yang menjadi lokasi pilihan, BMT UGT Sidogiri juga memilih dan membidik daerah-daerah yang menjadi kantong tenaga kerja. Alasannya adalah bahwa selain daerah semacam ini menjadi tempat perputaran uang juga akan menjadi lahan dakwah dalam rangka meminimalkan praktik rentenir dan riba di masyarakat sekitar. Hal ini sesuai dengan visi dan misi BMT UGT Sidogiri yaitu "Terbangunnya dan berkembangnya ekonomi umat dengan landasan Syariat Islam; Terwujudnya budaya ta'awun dalam kebaikan dan ketakwaan di bidang sosial-ekonomi; Menerapkan dan memasyarakatkan Syariat Islam dalam aktivitas ekonomi."

Penerapan strategi lokasi ini juga disertai dengan strategi jaringan, yaitu dengan memperbanyak jaringan kantor cabang pembantu dan kantor pelayanan. Tujuan strategi ini adalah selain untuk mencapai jumlah pelanggan yang optimal pada waktu yang tepat dan dengan biaya yang rendah juga agar dapat meraih dan menjaga tingkat pengendalian jaringan tertentu.

Terkait dengan strategi distribusi adalah faktor ketersediaan sarana transportasi. Ketersediaan dan keterjangkauan sarana transportasi merupakan salah salah faktor kesuksesan distribusi produk dari suatu perusahaan penjual barang dan jasa. BMT UGT Sidogiri secara cermat juga menjadikan hal ini sebagai salah satu pertimbangan penting dalam setiap usaha membuka kantor cabang dan kantor cabang pembantu di mana lokasinya selalu berada di pusat keramaian serta mudah dijangkau oleh nasabah baik dengan transportasi pribadi maupun umum. 
Satu hal yang-menurut hemat penulis-cukup menarik adalah keterlibatan para alumni Pesantren Sidogiri dalam mengembangkan usaha BMT UGT Sidogiri. Kaitannya dengan hal ini, lembaga keuangan tersebut memberdayakan para alumni untuk menjadi agen dan distributor produk dengan membuka kantor pelayanan di seluruh pelosok negeri yang memungkinkan. Ini merupakan salah satu strategi bauran yang diterapkan oleh BMT UGT Sidogiri untuk mendukung penerapan strategi lokasi dan distribusi. Strategi ini sangat berhasil yang dibuktikan dengan peningkatan jumlah kantor layanan di mana pada tahun 2013 berjumlah 228 unit kemudian meningkat jumlahnya menjadi 257 unit pada tahun 2014.

Keberhasilan strategi distribusi produk BMT UGT Sidogiri tidak terlepas dari dipegangteguhnya etika sharî‘ ah di mana distribusi harus menciptakan nilai dan peningkatan standar hidup dengan menyediakan layanan memuaskan secara etis dan juga telah mengikuti prinsip-prinsip tidak memanipulasi ketersediaan produk untuk tujuan eksploitasi, tidak menggunakan pemaksaan dalam saluran produk, tidak mempengaruhi secara tidak pantas kepada nasabah untuk memilih produk serta saluran distribusi tidak seharusnya membuat beban bagi pelanggan akhir, baik dari segi harga lebih tinggi maupun penundaan. ${ }^{22}$ Hal inilah yang selanjutnya menjadikan perbedaan filosofis yang sangat mendasar antara sharî'ah marketing dan conventional marketing di mana yang disebut terakhir merupakan pemasaran yang bebas nilai dan tidak mendasarkan setiap aktivitas pemasarannya pada nilai-nilai ketuhanan.

4. Strategi promosi

Dalam melakukan promosi/sosialisasi kepada masyarakat, BMT UGT Sidogiri menggunakan strategi bauran promosi atau disebut juga promotion mix, promotion blend, dan communication mix di mana strategi ini mencakup personal selling, mass selling yang terdiri atas periklanan dan publisitas, promosi penjualan, public relations dan direct marketing.

Dalam bidang periklanan, BMT UGT Sidogiri mensosialisasikan produk-produknya melalui iklan cetak, siaran radio, brosur, poster dan selebaran, billboard/papan nama meskipun promosi dengan bentuk ini, sejauh pengamatan penulis, bisa dibilang masih dalam lingkup kecil dan terbatas (belum maksimal). Selanjutnya, personal selling dilakukan dengan komunikasi langsung (tatap muka) antara penjual produk dan calon

22 Ibid., 344. 
pelanggan untuk memperkenalkan produk kepada calon pelanggan dan membentuk pemahaman yang baik dalam diri pelanggan terhadap produk, sehingga mereka kemudian akan mencoba dan membelinya. Menariknya, dalam menjalankan strategi ini pihak BMT UGT Sidogiri juga melakukan pendekatan kepada para para tokoh agama yang menjadi panutan masyarakat. Dalam hal ini, pihak BMT akan meminta waktu, misalnya, dalam event-event pengajian keagamaan untuk memperkenalkan berbagai produk BMT UGT Sidogiri. Di kalangan marketer produk BMT UGT Sidogiri, hal ini dinamakan strategi “jaring ikan". Strategi inilah yang menjadi salah satu andalan tenaga pemasaran lembaga ini.

Selain hal di atas, BMT UGT Sidogiri juga menerapkan berbagai terobosan untuk menyukseskan strategi promosi seperti pengadaan undian, pemberian beasiswa, gebyar hadiah, pemberian kupon, gratis cover asuransi pada beberapa item produk, setoran awal yang rendah dan jaminan produk yang membuat nasabah/konsumen semakin tertarik. Adapaun dalam bidang public relations, BMT UGT Sidogiri gencar melakukan sosialisai diri dalam bentuk:

1. Seminar-seminar dan kampanye ekonomi sharî‘ ${ }^{\natural}$ h kepada masyarakat luas.

2. Menerima studi banding dari lembaga-lembaga pendidikan maupun instansi tertentu.

3. Bekerja sama dengan lembaga-lembaga keuangan seperti Bank Syariah Mandiri, Bank Panin Syariah, BNI Syariah, BRI Syariah, Bank Muamalat Indonesia, Bank Bukopin Syariah, Bank Danamon Syariah, BCA Syariah, Bank DKI Syariah, INKOPSYAH BMT Jakarta, Tazkia Institute dan PUSKOPSYAH Jatim dalam berbagai event penting.

4. Bekerja sama dengan lembaga non-perbankan seperti INKOPSYAH BMT Jakarta, PT. Permodalan BMT Ventura, PT. Value Stream Indonesia, PT. Negakom Indonesia, ABSINDO, Tazkia Institute, PT. GCN Jakarta, CV. Fath Jaya Sentosa, PT. Nurani Travel, PT. Telkomsel, PT. AKSES, PT. Turen Indah Property, Miami Bestman, PT. Toyota, PT. Daihatsu, MPM Motor Honda dan PUSKOPSYAH Jatim.

5. Bekerja sama dengan beberapa lembaga pendidikan untuk penyaluran beasiswa, seperti dengan Tazkia Institute Bogor. 
6. Memberikan pembinaan-pembinaan berkenaan dengan lembaga keuangan sharî‘ ah pada masyarakat/kelompok yang membutuhkanya.

7. Pembuatan buku laporan tahunan.

Di atas semuanya terdapat hal penting yaitu bahwa dalam melakukan promotion mix, BMT UGT Sidogiri tidak melanggar etika sharî‘ah Islam seperti yang dijelaskan di dalam al-Qur'ân yang mengutuk segala bentuk pernyataan palsu, tuduhan tak berdasar, pemaksaan dan kesaksian palsu. ${ }^{23}$ Dengan kata lain, tidak etis bagi penjual melebih-lebihkan keunggulan produk yang ia jual yang sebenarnya tidak ada. Kaitannya dengan hal ini BMT UGT Sidogiri sangat menghindari periklanan palsu dan menyesatkan; praktik penjualan yang menyesatkan; promosi penjualan yang menggunakan penipuan dan manipulasi; penggunaan teknik promosi yang menonjolkan daya tarik seksual, perempuan, kesaksian dan penelitian palsu, kontribusi pada kebodohan pikiran atau mendorong pada terjadinya pemborosan. ${ }^{24}$ Lembaga ini mensyaratkan nilai kejujuran yang tinggi pada setiap individu tenaga pemasarannya dengan prinsip keteladanan kepada Nabi Muhammad. Bagi BMT UGT Sidogiri, seorang pemasar sharî‘ah akan secara jujur menceritakan kelebihan dan kekurangan produk yang ditawarkannya. Hal ini merupakan praktik perniagaan yang dicontohkan oleh Rasulullah.

\section{Catatan Akhir}

Untuk mendapatkan hasil pemasaran yang sesuai dengan harapan, maka produsen setidaknya harus mengikuti beberapa tahapan atau proses pemasaran, yaitu pengenalan pasar, strategi pemasaran, bauran pemasaran, dan evaluasi. Hal ini penting dilakukan karena kegiatan pemasaran sangat menentukan sampai atau tidaknya produk yang dihasilkan oleh perusahaan kepada konsumen. Marketing mix (bauran pemasaran) adalah salah satu tahapan dalam proses pemasaran di mana produsen harus bisa menerapkannya secara tepat untuk memenuhi keinginan konsumen. Jika strategi ini berhasil dijalankan, maka suatu perusahaan akan mencapai target pemasaran yang diinginkan.

BMT UGT Sidogiri Pasuruan adalah salah satu lembaga keuangan sharî‘ah yang sukses menerapkan strategi bauran pemasaran sehingga lembaga ini mengalami perkembangan yang sangat pesat. Berdasarkan hasil pembahasan dan analisa yang dilakukan, penulis menyimpulkan

23 Ibid., 102-03.

24 Ibid. 
bahwa BMT UGT Sidogiri mengalami perkembangan yang sangat signifikan selama kurang lebih 14 tahun eksistensinya. Hal ini tidak terlepas, antara lain, dari diterapkannya strategi bauran pemasaran yang mencakup: pertama, strategi produk yang dilakukan dengan menawarkan produk yang bervariasi dan beranekaragam kepada nasabah. Salah satu hal penting dalam strategi ini adalah bahwa BMT UGT Sidogiri menjamin kehalalan semua produknya. Dengan kata lain, BMT UGT Sidogiri menjamin bahwa produk-produknya sepenuhnya sesuai dengan sharî‘ah, mengedepankan nilai keadilan, keterbukaan dengan margin yang telah disepakati oleh pihak BMT dan nasabah dengan prinsip kesepakatan yang kompetitif dan tidak membebani nasabah. Kedua, strategi penentuan harga dengan mengutamakan nilai keadilan yang merupakan ciri dari lembaga keuangan syariah. Dalam konteks ini penulis menemukan bahwa, memang, harga yang ditetapkan oleh BMT UGT Sidogiri relatif sama dengan BMT-BMT lain. Meskipun demikian, menurut hemat penulis, ada beberapa hal yang menjadi keunggulan strategi harga yang diterapkan oleh BMT UGT Sidogiri yaitu selain persyaratan yang memudahkan nasabah juga jangka waktu kredit untuk setiap item produk yang berbeda-beda dan variatif sesuai dengan pilihan nasabah/konsumen. Dengan demikian nasabah memiliki alternatif pilihan produk keuangan sesuai dengan kebutuhannya. Ketiga, strategi lokasi/distribusi di mana BMT UGT Sidogiri memfokuskan diri pada tempat-tempat potensial diantaranya pasar-pasar tradisional dan membidik daerah-daerah yang menjadi kantong tenaga kerja. Selain itu, BMT UGT Sidogiri memberdayakan para alumninya untuk memperluas jaringan kantor pelayanan. Hal ini memungkinkan terciptanya jaringan yang kuat pada lembaga keuangan ini. Hal inilah yang menjadi salah satu penyebab berkembangnya lembaga ini secara massive dan siginifikan. Keempat, strategi sosialisasi/promosi kepada masyarakat yang dilakukan dengan strategi bauran promosi (promotion mix) atau disebut juga dengan promotion blend atau communication mix di mana strategi ini mencakup personal selling, mass selling yang terdiri atas periklanan dan publisitas, promosi penjualan, public relations dan direct marketing. Strategi ini menjamin keberlangsungan proses pemasaran produk-produk yang dijual oleh BMT UGT Sidogiri.

Selain penerapan strategi bauran pemasaran yang efektif, ada beberapa faktor yang mempengaruhi pesatnya perkembangan BMT 
UGT Sidogiri, yaitu: pertama, kepatuhan yang kuat kepada prinsip-prinsip sharî‘ah Islam dalam setiap kegiatan pemasaran. Dalam konteks ini, BMT UGT Sidogiri sangat menjunjung tinggi empat karakteristik ya ng terdapat dalam pemasaran sharî'ah yaitu rabbânîyah, akblâqîyah, wâqi îyah, dan insânîyah. Kedua, BMT UGT Sidogiri menyadari sepenuhnya bahwa ia terbentuk dengan niat dakwah dan membumikan praktik kelembagaan keuangan sharî‘ah. Berdasarkan hal itulah setiap tenaga pemasar (marketer) dalam lembaga ini sadar bahwa pasar terbentuk berdasarkan perilaku (behavior) yang terbagi dalam tiga segmen, yaitu sharia loyalist, floating market dan conventional market. Dari ketiga segmen tersebut sharia loyalist adalah segmen terpenting dalam BMT UGT Sidogiri yang diposisikan sebagai partner sejajar dan bukan "sapi perahan" yang dapat dieksploitasi hanya untuk kepentingan perusahaan.

\section{Daftar Rujukan}

Antonio, M. Syafi'i. Bank Syariah dari Teori ke Praktek. Jakarta: Gema Insani, 2001.

Candra, Gregorius. Strategi dan Program Pemasaran. Yogyakarta: Andi Offset, 2005.

Hasan, Ali. Marketing Bank Syariah. Yogyakarta: Mitra Pustaka, 2007. http://www.republika.co.id/berita/ekonomi/syari'ah-

ekonomi/15/02/23/nk89rm- bmt-sidogiri-raih-dana-kemitraan-rp200-miliar.

Irawan dan Farid Wijaya M. Pemasaran: Prinsip dan Kasus. Edisi Kedua. Yogyakarta: BPFE, 1997.

Kasmir. Pemasaran Bank. Edisi Revisi. Jakarta: Prenada Media, 2008. Kertajaya, Hermawan dan Muhammad Syakir Sula. Syariah Marketing. Bandung: Mizan, 2006.

Kotler, Philip. Manajemen Pemasaran. Jakarta: Prenhallindo, 2002.

----. Marketing Essentials, terj. Herujati Purwoto. Jakarta: Erlangga, 1999.

Redaksi Majalah Ijtihad. Jejak Langkah 9 Masyayikh Sidogiri. Jilid 2.

Pasuruan: Pustaka Sidogiri Pondok Pesantren Sidogiri, 1432 H.

Sumarni, Murti. Marketing Perbankan. Yogyakarta: Liberty, 1997.

Susanto, Herry dan Khaerul Umam. Manajemen Pemasaran Bank Syari'ah.

Bandung: Pustaka Setia, 2013.

Wafi, Sholeh. Wawancara. Rabu 28 Januari 2015. 